\title{
New ZeALAND's OcEans Policy
}

\author{
Angela Foster*
}

In light of recent Oceans Policy developments this paper proposes a legal and institutional framework for the management of New Zealand's oceans. It focuses on one key existing problem: the lack of a comprehensive, coherent framework for the sustainable management of the marine environment. The proposed framework addresses this issue by suggesting an overarching statute, based on the approach taken by the Resource Management Act, under which several layers of policy refinement and implementation create national consistency coexisting with localised solutions based on the purpose of sustainability and broad guiding principles. The proposal is consistent with New Zealand's international obligations, other domestic legislation and existing institutional structures. The paper concludes with a statement on the importance to our future wellbeing of developing a comprehensive and enduring Oceans Policy.

\section{INTRODUCTION}

This paper discusses the drivers behind the development of New Zealand's Oceans Policy and proposes a legal and institutional framework for the management of New Zealand's oceans. The Oceans Policy is being developed in three stages through the Office of Hon P Hodgson, MP as the Minister Responsible for Oceans Policy and by the Oceans Policy Secretariat. Following the introduction of Part I, Part II briefly outlines New Zealand's marine jurisdiction and the importance of the marine environment to New Zealand's broader interests. Part III discusses the reasons why New Zealand needs an Oceans Policy. Part IV summarises the development to date of New Zealand's Oceans Policy. Part V examines the context within which New Zealand must develop its Oceans Policy including its international obligations, domestic legislation and policy, and the Treaty of Waitangi. Based on New Zealand's existing legislation and international obligations I propose a legal and institutional framework to manage New Zealand's oceans in Part VI.

This paper concludes that New Zealand's Oceans Policy should provide a coherent strategic planning and management framework for dealing with the competing marine-use issues that arise between different interest groups. My proposed framework comprises an overarching Oceans

* This article is an edited version of a paper submitted in fulfilment of the requirements of the LLB(Hons) degree at Victoria University of Wellington, 2002. 
Management Act, a New Zealand Oceans Strategy, Regional Marine Plans and regulations. The overarching framework I propose under the Oceans Management Act should aim to strike a balance between a comprehensive and flexible framework, thereby responding to regional diversity, providing security and certainty for existing users, and accommodating unrealised uses without having to rewrite the legislation or policy each time a new use is developed.

\section{CONTEXT}

New Zealand ratified the United Nations Convention on the Law of the Sea (UNCLOS) in July 1996. ${ }^{1}$ The Convention provides the basic legal framework for oceans management and sets out the principles and norms that apply to party States. Under UNCLOS New Zealand gained rights and responsibilities over approximately 4 million square kilometres of sea: an area over 15 times the size of New Zealand's land mass. ${ }^{2}$ New Zealand has a rich diversity of marine ecosystems ${ }^{3}$ within its jurisdiction. It includes over 8,000 identified marine species, ${ }^{4}$ subtropical and icy waters, $15,000 \mathrm{~km}$ of coastline, ${ }^{5}$ deep sea trenches and seamounts. ${ }^{6}$

The richness and diversity of New Zealand's marine environment provides potential for both present and future generations. The marine environment provides numerous opportunities for commercial, customary and recreational fishing, mineral production, transportation, tourism and

1 United Nations Convention on the Law of the Sea, (10 December 1982) 1836 UNTS 3. New Zealand ratified this on 19 July 1996 however, it did not come into effect in New Zealand until 18 August 1996: Ministry for the Environment Multilateral International Environment Agreements in Force in New Zealand: $<$ http://www.mfe.govt.nz/laws/meas/meas-in-force.html> (last accessed 16 March 2003).

2 Ministerial Advisory Committee Healthy Sea: Healthy Society - Towards an Oceans Policy for New Zealand (Oceans Policy Secretariat, Wellington, 2001) 14.

3 An ecosystem is a "dynamic complex of plant, animal and micro-organism communities and their non-living environment interacting as a functional unit": United Nations Convention on Biological Diversity (5 June 1992) 1760 UNTS 79, art 2.

4 New Zealand Government's Oceans Policy website Oceans Policy Brochure under the "What's New?" tab $<$ http://www.oceans.govt.nz/libraryElements/publicDocuments/Oceans_DL_final.pdf $>$ (last accessed 30 March 2003).

5 This includes estuaries, fiords, rocky shorelines, beaches and harbours: Ministerial Advisory Committee Healthy Sea: Healthy Society - Towards an Oceans Policy for New Zealand (Oceans Policy Secretariat, Wellington, 2001) 19.

6 Seamounts are underwater hills and mountain ranges, with many containing species that are unique to the seamount on which they are found or to New Zealand. The information in the main body and footnote was sourced from the New Zealand Government's Oceans Policy website Oceans Policy - Information Sheet No $1-$ New Zealand's Marine Environment: What are we Dealing With? $<$ http://www.oceans.govt.nz/library/libraryfra3.html> (last accessed 20 June 2002). However, at the date of publication, the link to the New Zealand Government's Oceans Policy website containing this information had been removed. The Information Sheet should still be available by contacting the Oceans Policy Secretariat (responsible for the website) and requesting the information under the Official Information Act 1982. 
research. ${ }^{7}$ It is also home to thousands of marine mammals and other species, while acting as an involuntary sponge to absorb land based pollution and, amongst other things, dumped materials. ${ }^{8}$ New Zealand's marine environment is therefore integral to the continuing social, cultural, spiritual, environmental and economic health of New Zealand and its contribution to the health of the rest of the world.

However, increased pressures and demands have been and will continue to be placed on the oceans, threatening the biodiversity and ecological integrity of many marine ecosystems. These pressures include increases not only in New Zealand's coastal population, causing degradation of the marine environment from the impact of land uses; but also in the world's population, causing global over-exploitation of fish stocks. ${ }^{9}$ Further, the potential of technological capabilities to exploit resources before they have time to recover, as well as a lack of knowledge about the marine environment may cause irreparable damage, therefore limiting the options of future generations. ${ }^{10}$

There is a need to proactively conserve and protect the marine environment and its resources for future generations, whilst still being able to utilise them today.

\section{NEW ZEALAND'S OCEANS POLICY: THE MOTIVES}

Several factors motivated the New Zealand government to undertake the development of an Oceans Policy for its marine environment. First, there was increasing recognition, both domestically and internationally, of the need for effective management of the impacts of human activity on the marine environment. ${ }^{11}$ Secondly, 1998 was designated as Year of the Oceans by the United Nations. This had the effect of focusing attention on oceans issues. ${ }^{12}$ Thirdly, Australia and Canada had both started to develop oceans strategies to direct the management of their respective oceans. ${ }^{13}$ Fourthly, environmental groups had argued for a comprehensive strategy to manage the marine environment in a more integrated and co-ordinated way. ${ }^{14}$ Furthermore, the New Zealand Biodiversity Strategy, launched in March 2000, had a number of goals in relation to the marine environment. This Strategy could not successfully be undertaken in isolation from other marine

7 See generally, Ministerial Advisory Committee Healthy Sea: Healthy Society - Towards an Oceans Policy for New Zealand (Oceans Policy Secretariat, Wellington, 2001).

8 Ministerial Advisory Committee, above.

9 New Zealand Marine Services Society Submission on the Development of an Oceans Policy for New Zealand (submission to Ministerial Advisory Committee on Oceans Policy, 2001) 3.

10 New Zealand Marine Services Society, above, 3.

11 "Memorandum for the Cabinet Policy Committee: Oceans Policy" (17 July 2000) CAB(00) M23/2C, para 7.

12 Memorandum for the Cabinet Policy Committee, above, para 8.

13 Memorandum for the Cabinet Policy Committee, above, para 8.

14 Memorandum for the Cabinet Policy Committee, above, para 11. 
environment issues. ${ }^{15}$ Finally, perhaps the most influential motive was the Parliamentary Commissioner for the Environment's report on the management of the marine environment. ${ }^{16}$ Cumulatively, these factors formed the impetus to start the development process in motion.

The Parliamentary Commissioner for the Environment's report Setting Course for a Sustainable Future: The Management of New Zealand's Marine Environment (the PCE Report) recommended the development of an Oceans Policy to integrate management of the marine environment. ${ }^{17}$ The PCE Report found that there is currently no overarching framework or strategy to guide stakeholders towards sustainable management of the marine environment. ${ }^{18}$ To date, the focus of the sustainable management of New Zealand's environment has been on terrestrial activity. ${ }^{19}$ Furthermore, there was no effective mechanism in place to resolve the incompatible goals of legislation. ${ }^{20}$ The Parliamentary Commissioner for the Environment was of the view that: ${ }^{21}$

[T] he major need is for a complete reappraisal of the institutional, legal and knowledge bases with which we manage the marine environment. Fundamental changes are needed in the way we see the sea and ultimately value its resources. It is unlikely that the necessary progress can be made by continuous iteration of the complex and disjointed systems we have evolved to date.

The PCE Report identified that a management regime for the marine environment was needed which would involve "a strategy comprising firstly, goals and principles, and secondly, actions and policies for the future sustainable management of the marine environment". ${ }^{22}$ On the Parliamentary Commissioner for the Environment's recommendation a Ministerial Group was set up in July 2000 to oversee the development of an Oceans Policy. ${ }^{23}$ The Oceans Policy will be designed to resolve three main problems with the current regulatory framework, namely: ${ }^{24}$

15 Memorandum for the Cabinet Policy Committee, above, para 10.

16 Memorandum for the Cabinet Policy Committee, above, para 9.

17 Parliamentary Commissioner for the Environment Setting Course for a Sustainable Future: The Management of New Zealand's Marine Environment (Wellington, 1999) 99.

18 Parliamentary Commissioner for the Environment, above, 98.

19 Cath Wallace "Managing Resources in New Zealand" in Australian and New Zealand Society for Ecological Economics Inaugural Ecological Economics Conference (Coffs Harbour, NSW, 1995).

20 Parliamentary Commissioner for the Environment Setting Course for a Sustainable Future: The Management of New Zealand's Marine Environment (Wellington, 1999) 98.

21 Parliamentary Commissioner for the Environment, above, 98.

22 Parliamentary Commissioner for the Environment, above, 99.

23 Parliamentary Commissioner for the Environment, above, 99 and Memorandum for Cabinet Policy Committee "Oceans Policy" (17 July 2000) CAB(00) M23/2C.

24 Carolyn Risk, Oceans Policy Secretariat (Speech to the Resource Management Group of the Wellington District Law Society, Wellington, 8 May 2002). 
- the inability to manage the marine environment in a way that is consistent with its physical reality;

- conflict between activity specific management regimes; and

- gaps in the management regimes - activities for which there is no management regime.

\section{A The Physical Reality of the Marine Environment}

The marine environment within New Zealand's vast jurisdiction is comprised of a number of interrelated and interdependent components. The environment is a dynamic system that changes both naturally and from the impacts of human activities. ${ }^{25}$ Not only do the physical dimensions of the ocean interact with each other, ${ }^{26}$ but they also interact with the air and the land. In its submission to the Ministerial Advisory Committee for Stage One of the Oceans Policy development process, ${ }^{27}$ the Environment and Conservation Organisation noted that "management regimes for arbitrary subdivisions of marine environments cut across natural ecosystem boundaries and ignore interacting biophysical systems". 28

The marine environment is also connected naturally with the land and air: a change in any one will affect the others. ${ }^{29}$ Activities on the land, such as run off and sedimentation from agricultural land or the disposal of sewage, have negative impacts on the quality of water in coastal and estuarine areas and on the overall health of marine systems. ${ }^{30}$ Global warming and climate change have led to the sea level rising, which could seriously erode the coastline and considerably affect New Zealand's coastal towns and cities. ${ }^{31}$

\section{B Conflict Between Activity Specific Management Regimes}

The legal and policy framework to manage the marine environment has not been developed in line with the physical environment, but rather in response to individual or sectoral needs. The existing legislative framework relating to New Zealand's use of its marine environment is

25 Ministerial Advisory Committee Healthy Sea: Healthy Society - Towards an Oceans Policy for New Zealand (Oceans Policy Secretariat, Wellington, 2001) 20.

26 For example, the seabed, water column, marine life and ecosystems within the ocean.

27 For further information on the Oceans Policy development process, see Part IV.

28 Ministerial Advisory Committee, above, 20.

29 Ministerial Advisory Committee, above, 20.

30 SeaFIC Defining the Vision for New Zealand's Oceans (submission to Ministerial Advisory Committee on Oceans Policy, 2001) 5.

31 Ministerial Advisory Committee, 20. 
complicated, piecemeal and, in places, contradictory. ${ }^{32}$ The key problem facing the management of the oceans appears to be the lack of co-ordination over a wide range of legal regimes which were developed at different times to address particular issues. The Hon P Hodgson, MP, Minister Responsible for Oceans Policy, stated: ${ }^{33}$

there were currently at least 18 pieces of domestic legislation and fourteen departments of state involved in managing the marine environment. But there was no overall policy framework to ensure they worked together consistently, towards agreed goals.

This fragmented development has given rise to the present unsatisfactory scattering of marine management agencies and legislation as well as to a concomitant lack of uniformity in the development of higher level policy aims. ${ }^{34}$ Fundamentally, rectifying these problems lies at the heart of the Oceans Policy.

Moreover, whilst the present regulatory system is, at times, adequate in managing simple or specific sectoral uses, it is unable to manage the complex and conflicting multiple uses made of the marine environment. Problems arise when different groups or individual users with different priorities vie for the same space. One of the aims of an Oceans Policy will be to prevent and manage conflict between the different sectors through identifying priorities and goals and, where possible, integrating the sectoral uses made of the marine environment and its resources.

\section{Gaps in the Management Regimes}

With advances in technology, the marine environment and its resources have the potential to contribute significant economic benefits to New Zealand. However, the skills and knowledge behind these new technologies are being developed more quickly than the legal mechanisms to manage them are. ${ }^{35}$ For example, there is virtually no precedent for national policy or legislation to govern and regulate "bioprospecting". ${ }^{36}$ The Oceans Policy will need to cover the gaps in the current regulatory system, as well as be flexible enough to cover the potential gaps when new uses for the marine environment are discovered.

32 Hon Pete Hodgson, Minister Responsible for Oceans Policy "Oceans Policy Process Launched" (12 October 2000) Press Release.

33 Hon P Hodgson, above.

34 The complexities of the management of the marine environment are illustrated in Parliamentary Commissioner for the Environment Setting Course for a Sustainable Future (Wellington, 1999) 26-27.

35 Carolyn Risk, Oceans Policy Secretariat (Speech to the Resource Management Group of the Wellington District Law Society, Wellington, 8 May 2002).

36 Biodiversity prospecting is the exploration of wild plants and animals for commercially valuable genetic and biochemical resources: World Resources Institute "Questions and Answers About "Bioprospecting"" $<$ http://www.igc.org/wri/biodiv/bp-facts.html > (last accessed 16 March 2003). 


\section{Conclusion}

It is primarily the conflict between activity specific management regimes that represents the key problem in the current regulatory framework, as different sectors exercise rights under different management regimes that often conflict with each other. The existing system lacks a single overarching purpose and regulatory framework to guide and manage the competing and multiple uses made of the marine environment and its resources. The Parliamentary Commissioner for the Environment therefore recommended that an Oceans Task Force be established to develop a strategy for the sustainable and integrated management of the marine environment. ${ }^{37}$ The next Part summarises the developments to date of New Zealand's Oceans Policy.

\section{DEVELOPMENT OF NEW ZEALAND'S OCEANS POLICY}

In July 2000 the Minister Responsible for Oceans Policy, the Hon P Hodgson, MP, chaired an ad hoc Ministerial Group charged with developing New Zealand's Oceans Policy. ${ }^{38}$ The Ministerial Group is responsible for both economic and environmental outcomes affecting the marine environment. ${ }^{39}$ New Zealand's Oceans Policy is being developed in three stages: (One) defining the Vision, (Two) designing the tools to achieve the Vision and (Three) delivering the vision.

\section{A Stage One: Defining the Vision}

Stage One was publicly launched in October 2000, resulting in the November 2001 Healthy Sea: Healthy Society - Towards an Oceans Policy for New Zealand report. ${ }^{40}$ Based on the extensive consultation with the public and stakeholders, Cabinet approved the following aspirational "Vision" to reflect New Zealanders' values in relation to the marine environment: ${ }^{41}$

Healthy Oceans: New Zealanders understand marine life and marine processes and, accordingly take responsibility for wisely managing the health of the ocean and its contribution to the present and future social, cultural, environmental and economic wellbeing of New Zealand.

37 Parliamentary Commissioner for the Environment Setting Course for a Sustainable Future: The Management of New Zealand's Marine Environment (Wellington, 1999) 99.

38 Cabinet Finance, Infrastructure and Environment Committee "Oceans Policy" (18 September 2000), para 27. The Cabinet Paper reference number did not appear on the website from which it was sourced: $<$ http://www.oceans.govt.nz/library/libraryfra.html $>$ (last accessed 21 September 2002). However, at the date of publication, the link to the New Zealand Government's Oceans Policy website containing this Cabinet Paper had been removed. This information should still be available by contacting the Oceans Policy Secretariat (responsible for the website) and requesting the information under the Official Information Act 1982.

39 Cabinet Finance, Infrastructure and Environment Committee, above, para 27.

40 Ministerial Advisory Committee Healthy Sea: Healthy Society - Towards an Oceans Policy for New Zealand (Oceans Policy Secretariat, Wellington, 2001).

41 Cabinet Policy Committee "Oceans Policy" (3 December 2001) CAB Min (01) 37/5C. 
The advantage of such a broadly worded Vision is that a spectrum of outcomes can be catered for in the future. However, the generality of the Vision is also unsatisfying as it does not have any concrete visions that marine users today can factor into their decisions, so that they will be consistent with the future management regime. This prolongs the lack of certainty for all users of the marine environment. The Vision therefore appears to be not much more than a vague statement of social responsibility.

\section{B Stage Two: Designing the Tools to Achieve the Vision}

The Oceans Policy is currently at Stage Two of the development process. The aim of this stage is to design the tools to achieve the values that New Zealanders identified as important to them from the public and stakeholder consultations. The strategic objective of Stage Two is to produce a draft Oceans Policy to Cabinet by June 2003 and make it available for public consultation and discussion in July 2003. ${ }^{42}$ This draft will include goals and objectives for managing the marine environment. ${ }^{43}$ Subsequently, the operational tools and framework necessary to implement the Oceans Policy will be developed.

\section{Stage Three: Delivering the Vision}

This stage will deliver the policies, processes and tools to achieve the Vision, and the goals and objectives identified at Stage Two. In particular, legislation will be passed and institutional changes made to achieve the desired outcomes. ${ }^{44}$ Monitoring mechanisms will also be implemented to assess the extent to which progress is being made in achieving the Vision, thus identifying any further work that may be necessary. ${ }^{45}$

\section{Conclusion}

The Oceans Policy is currently at Stage Two of the development process. However, it is the content of Stage Three that will determine how the Oceans Policy will operate and it is this stage that directs the focus of this paper. In Part VII therefore propose a legislative and institutional

42 Ad hoc Ministerial Group on Oceans Policy "Oceans Policy: Stage Two Work Programme" (21 May 2002). The Cabinet Paper reference number did not appear on the website from which it was sourced: $<$ http://www.oceans.govt.nz/library/libraryfra.html $>$ (last accessed 21 September 2002). However, at the date of publication, the link to the New Zealand Government's Oceans Policy website containing this Cabinet Paper had been removed. This information should still be available by contacting the Oceans Policy Secretariat (responsible for the website) and requesting the information under the Official Information Act 1982.

43 Ad hoc Ministerial Group on Oceans Policy, above, 2.

44 Cabinet Finance, Infrastructure and Environment Committee "Oceans Policy" (18 September 2000) para 25. The Cabinet Paper reference number did not appear on the website from which it was sourced: $<$ http://www.oceans.govt.nz/library/libraryfra.html> (last accessed 21 September 2002).

45 Cabinet Finance, Infrastructure and Environment Committee, above, para 25. 
framework that will "deliver the Vision". First, however, to inform my proposed framework, it is necessary to traverse New Zealand's international and domestic obligations. These are described in Part V and, from this, principles are gleaned to manage the multiple uses of New Zealand's oceans and its resources.

\section{PRINCIPLES ARISING FROM NEW ZEALAND'S INTERNATIONAL AND DOMESTIC LEGISLATION OBLIGATIONS}

\section{A Introduction}

Given that the key problem identified in Part III is the conflict between activity specific management regimes developed at different times, one of the main aims of the Oceans Policy will be to successfully manage the conflicting and multiple uses made of the oceans. Multiple use management is therefore one of the key challenges for New Zealand's Oceans Policy. However, this must be managed consistently with our international obligations and domestic framework. As the development of New Zealand's Oceans Policy will not occur in a vacuum, the foundational legislation and obligations are important in informing the content of my proposed legislative framework. This Part discerns principles from New Zealand's existing legislation and international obligations for the multiple use management of New Zealand's oceans. These include varying definitions of sustainability, utilisation of resources, intergenerational equity, precaution, conservation, integrated management, public participation, responsibility, ecosystem integrity and the principles of the Treaty of Waitangi.

\section{B International Instruments}

Limitations on space require that this paper outlines only two of New Zealand's key multilateral environmental agreements (MEA), and New Zealand's obligations under them, concerning the oceans and its resources. Under international law, these obligations are owed to other contracting states to the particular MEA. It is important, therefore, that New Zealand's Oceans Policy be consistent with its international obligations to prevent disciplinary measures being taken against New Zealand. More importantly, however, is New Zealand's relationship with other states. New Zealand will not want to endanger its reputation and standing within the international community by implementing an Oceans Policy that is inconsistent with its obligations and responsibilities. Furthermore, another constraint on the development of New Zealand's Oceans Policy is that the health of the seas and oceans surrounding New Zealand cannot be viewed in isolation, but must also be seen as one component of a global resource. Thus, how New Zealand manages the marine environment and its resources not only affects New Zealand, but may also affect the environmental, social and economic interests of New Zealand's South Pacific neighbours and other States.

In developing New Zealand's Oceans Policy, compliance with the international legal framework will therefore be extremely important, not only because of the ramifications of non-compliance for New Zealand, but also because of the benefits accruing to the international community and the health of the world's oceans as a global entity. 


\section{United Nations Convention on the Law of the Sea [UNCLOS]}

UNCLOS came into effect in New Zealand on 18 August 1996. It has been described as the "constitution of the oceans". ${ }^{46}$ UNCLOS is the international response to the $20^{\text {th }}$ century acceleration of human use of the ocean, prompted by degradation of the oceans, the collapse of major fisheries due to over-harvesting, international conflict over resource access and a rising awareness among coastal States of the value of the oceans. ${ }^{47}$ UNCLOS codifies customary international law about the sea, laying down a comprehensive regime to govern all uses of the ocean and its resources. ${ }^{48}$ In particular, it sets out party States' entitlements and responsibilities. The Convention facilitates a multiple use regime by balancing all competing uses, but leaves it up to each party State to prioritise the interests according to its own policy.

New Zealand has sovereignty over its territorial waters ${ }^{49}$ and sovereign rights over its EEZ and continental shelf. ${ }^{50}$ Broadly, article 56 of UNCLOS allows New Zealand to explore and exploit its living and non-living resources within its EEZ. Article 62 provides that New Zealand, as a coastal State, shall promote the "optimum utilization" of the living resources. ${ }^{51}$ That, however, is subject to the conservation of living resources provided for in article 61. Additionally, article 192 places an unqualified obligation on States parties, including New Zealand, "to protect and preserve the marine environment". Although natural resources within New Zealand's EEZ may be exploited pursuant to any environmental policies, these are constrained by the overriding obligations under article 192. As will be discussed below, New Zealand has undertaken several initiatives to give effect to these articles.

Furthermore, the Preamble to UNCLOS declares that the seabed, ocean floor, subsoil and its resources that are not the subject of any state's jurisdiction belong to the common heritage of mankind and that exploration and exploitation of such shall be carried out for the benefit of mankind as a whole. ${ }^{52}$ Instead of reflecting any particular State's entitlements or obligations there

46 Douglas Johnston and David VanderZwaag "The Ocean and International Environmental Law: Swimming, Sinking and Treading Water at the Millennium" (2000) 43 Ocean and Coastal Management 141, 143.

47 Russell E Reichelt and Angus D McEwan "Australia's Marine Science and Technology Plan: An Action Plan for Australia's Ocean Policy" (1999) 50 Marine Freshwater Research 711, 711.

48 David R Rothwell "The Legal Framework for Ocean and Coastal Management in Australia" (1996) 43 Ocean and Coastal Management 41, 42.

49 United Nations Convention on the Law of the Sea, (10 December 1982) 1836 UNTS 3. New Zealand ratified this on 19 July 1996 however, it did not come into effect in New Zealand until 18 August 1996: Ministry for the Environment Multilateral International Environment Agreements in Force in New Zealand: $<$ http://www.mfe.govt.nz/laws/meas/meas-in-force.html> (last accessed 16 March 2003), art 2.

50 United Nations Convention on the Law of the Sea 1982, arts 56 and 77.

51 United Nations Convention on the Law of the Sea 1982, art 62(1).

52 United Nations Convention on the Law of the Sea 1982, Preamble. 
is a need to address these issues at an international or global level, reflecting the common interest in sustainable ocean governance.

\section{Chapter 17: Agenda 21}

One of the outcomes of the 1992 United Nations Conference on Environment and Development held in Rio de Janeiro was Agenda 21 which listed objectives, guiding principles and key priorities for the environment. Under international law it has the status of "soft law", meaning the principles that govern parties' actions are not legally binding. ${ }^{53}$ Agenda 21 sets up a framework utilising some of the guiding principles contained in the Rio Declaration ${ }^{54}$ to promote sustainable development including, for example, the precautionary approach, intergenerational equity, integrated management, polluter pays, user pays, public participation and indigenous peoples' rights.

In particular, Chapter 17 of Agenda 21 is devoted to the protection of the ocean, seas and coastal areas as well as the protection, rational use and development of their living resources. ${ }^{55}$ It proposes a plan of action and how to implement the principle of sustainable development that governments and local authorities can use. It also calls for a strengthening of international and regional co-operation. Agenda 21 differs from UNCLOS in that it adopts an ecosystem-based, rather than a jurisdictional, approach. As will be discussed below, New Zealand has implemented legislation and policies that largely accord with the themes of sustainable development and the principles expounded in the Rio Declaration and Chapter 17 of Agenda 21.

\section{Domestic Legislation and Policy Initiatives}

Despite the proliferation of international instruments that cover a wide spectrum of often conflicting or overlapping interests, New Zealand has incorporated several of its international obligations into domestic legislation or national strategies. This shows New Zealand's substantive commitment to conform with globally negotiated standards of environmental responsibility. The main legislative or policy tools which deal with the marine environment include the Resource Management Act 1991, the New Zealand Coastal Policy Statement, the Fisheries Act 1996, the New Zealand Biodiversity Strategy and the Environmental Performance Indicators programme. The remainder of this section describes the principles that guide these domestic initiatives, as these

53 Douglas Johnston and David VanderZwaag "The Ocean and International Environmental Law: Swimming, Sinking and Treading Water at the Millennium" (2000) 43 Ocean and Coastal Management 141, 145.

54 The Rio Declaration was another outcome of the 1992 United Nations Conference on Environment and Development: Report of the United Nations Conference on Environment and Development (A/CONF. 151/26 (Vol 1), United Nations, Rio De Janiero, 1992). Also available at $<$ http://www.un.org/documents/ga/conf151/aconf15126-1annex1.htm> (last accessed 16 March 2003).

55 The Rio Declaration was another outcome of the 1992 United Nations Conference on Environment and Development: Report of the United Nations Conference on Environment and Development (A/CONF. 151/26 (Vol 1), United Nations, Rio De Janiero, 1992). Also available at $<$ http://www.un.org/documents/ga/conf151/aconf15126-1annex1.htm> (last accessed 16 March 2003). 
principles will assist the development of a proposed framework for managing the marine environment.

\section{The Resource Management Act 1991 (the RMA)}

The RMA radically reformed the law relating to the use of land, air and water. Due to a considerable fragmentation in decision making, a "one stop shop" approach was introduced via the RMA so that the proposed activity and its impacts on the environment would be considered as a whole, thereby providing a context for the decision, integration and greater certainty for resource consent applicants. ${ }^{56}$ The RMA revoked 167 separate Acts and abolished 700 statutory authorities. $^{57}$

The RMA has a single, overarching purpose to "promote the sustainable management of natural and physical resources" ${ }^{58}$ as well as a series of principles to guide decision making. ${ }^{59}$ The Act defines sustainable management as "managing the use, development, and protection of natural and physical resources in a way, or at a rate, which enables people and communities to provide for their social, economic, and cultural well-being ${ }^{60}$ while also providing for the needs of future generations, ${ }^{61}$ safeguarding the life-supporting capacity of water and ecosystems, ${ }^{62}$ and mitigating any adverse effects". ${ }^{63}$ The RMA provides for stakeholder participation and integrated community decision making within the hierarchy of policies and plans. ${ }^{64}$ At the top of the hierarchy of planning documents are National Policy Statements and Standards, which must be consistent with the Purpose and Principles of the Act. The only mandatory National Policy Statement, the New Zealand Coastal Policy Statement, is discussed below.

The RMA, with its focus on sustainable management and integrated approach, is a major change in legislative direction for management of the environment. Rather than an activities based approach, the RMA focuses on impacts and outcomes. Its approach is to control externalities based

56 Cath Wallace "Managing Resources in New Zealand" in Australian and New Zealand Society for Ecological Economics Inaugural Ecological Economics Conference (Coffs Harbour, NSW, 1995).

57 Marcus Haward "Institutional Design and Policy Making 'Down Under': Developments in Australian and New Zealand Coastal Management" (1995) 26 Ocean and Coastal Management 87, 104.

58 Resource Management Act 1991, s 5.

59 Resource Management Act 1991, ss 6-8.

60 Resource Management Act 1991, s 5(2).

61 Resource Management Act 1991, s 5(2)(a).

62 Resource Management Act 1991, s 5(2)(b).

63 Resource Management Act 1991, s 5(2)(c).

64 Cath Wallace "Managing Resources in New Zealand" in Australian and New Zealand Society for Ecological Economics Inaugural Ecological Economics Conference (Coffs Harbour, NSW, 1995). 
on environmental impact assessments. ${ }^{65}$ The RMA therefore provides for greater flexibility and allows for regional variations. Thus, regional and district plans reflect not only the differences due to specific circumstances or impacts on the particular ecosystem, but also leaves each district or region to prioritise its own social, economic and cultural goals within the limits of the national priority of sustainable management and its principles. Thus no two regional or district plans need be the same. Also, due to the RMA's flexibility, an ecosystem approach can be catered for. The RMA is a comprehensive and overarching legislative framework that gives effect to the principles in the Rio Declaration and Agenda 21 in relation to land and the coastal environment. It provides a great model and benchmark for the development of an oceans policy based on sustainability, integration and an ecosystem approach.

\section{The New Zealand Coastal Policy Statement (the NZCPS)}

The purpose of the NZCPS is "to state policies in order to achieve the purpose of [the Resource Management] Act in relation to the coastal environment of New Zealand". 66 Sustainable management is also the key purpose, therefore, behind this National Policy Statement as well as the principles laid down in sections 6-8 of the RMA. The NZCPS provides an overarching set of national priorities for the preservation, protection and development of the coastal environment. Provision is also made for the protection of characteristics of special value to the tangata whenua ${ }^{67}$ and that the Principles of the Treaty of Waitangi must be taken into account in relation to Crown land in the coastal marine area. ${ }^{68}$ Finally, due to the relative lack of understanding and knowledge about coastal processes and the effects of activities on those processes, the NZCPS requires that the precautionary approach be adopted in relation to activities with unknown but potentially significant adverse effects. ${ }^{69}$ This picks up on the wording of the Rio Declaration and Chapter 17 of Agenda 21. Like the RMA, the NZCPS allows for regional variation within the umbrella concept of sustainable management.

\section{The Fisheries Act 1996}

The purpose of the Fisheries Act is to provide for both the utilisation and sustainability of fisheries resources. ${ }^{70}$ In particular, the Purpose and Principles contained in Part II of the Act give effect to New Zealand's obligations arising from the United Nations Convention on the Law of the

65 Resource Management Act 1991, s 88.

66 Resource Management Act 1991, s 56.

67 Department of Conservation New Zealand Coastal Policy Statement (Department of Conservation, Wellington, 1994) Policy 2.1.

68 New Zealand Coastal Policy Statement, above, Policy 4.2.

69 New Zealand Coastal Policy Statement, above, Policy 3.3.

70 Fisheries Act 1996, s 8(1). 
Sea in relation to fishing. To that end the principle of intergenerational equity, that is, that the reasonably foreseeable needs of future generations must not be jeopardised, is imported into the definition of "ensuring sustainability" in section $8(2)$, as is the obligation to avoid, remedy or mitigate any adverse effects on the aquatic environment. Further, section 9 requires that three environmental principles, with their origins in UNCLOS, be taken into account by decision-makers in relation to the utilisation or sustainability of fisheries resources. In that regard, section 9 provides that the impacts on associated or dependent species be managed $;^{71}$ that the marine biodiversity be maintained $;^{72}$ and that habitats of particular significance for fisheries management should be protected. ${ }^{73}$ Thus, the indirect effects of fishing are also relevant. Key features of the Act include a clear enunciation of the precautionary principle; ${ }^{74}$ the requirement to consult interested persons, as well as to provide for the input and participation of tangata whenua; ${ }^{75}$ and giving effect to non-commercial customary fishing rights. ${ }^{76}$ Finally, an interesting facet of the Act is its focus on "quota management areas". ${ }^{77}$ This may not be consistent with an environmental approach, which focuses on the management of the physical reality of marine ecosystems.

4 The New Zealand Biodiversity Strategy (the NZBS or the Strategy)

One response to New Zealand's obligations under the United Nations Convention on Biological Diversity was the NZBS. ${ }^{78}$ The NZBS provides a comprehensive strategic framework for the conservation and sustainable use of New Zealand's biodiversity. It is a veritable model for an action plan for the management of the oceans. It has a Vision, four goals and 13 principles for managing New Zealand's biodiversity and the implementation of the Strategy. Whilst the goals relate primarily to biodiversity issues, the principles are more relevant to this discussion.

The principles expounded in the NZBS elaborate on the international environmental law principles which have arisen under many of New Zealand's binding and non-binding multilateral agreements, notably Agenda 21 and the Rio Declaration. The 13 principles include Governance, Treaty of Waitangi, Collective and Ethical Responsibilities, Working Together, Respect for

71 Fisheries Act 1996, s 9(a).

72 Fisheries Act 1996, s 9(b).

73 Fisheries Act 1996, s 9(c).

74 Fisheries Act 1996, s 10(d).

75 Fisheries Act 1996, s 12.

76 Fisheries Act 1996, ss 174-186B.

77 Fisheries Act 1996, ss 24-26.

78 The United Nations Convention on Biological Diversity (15 June 1992) 1760 UNTS 79 was another outcome of the United Nations Conference on Environment and Development (discussed at Part VB2) which has an impact on the marine environment. The Convention on Biological Diversity was ratified by New Zealand on 16 September 1993 and came into effect on 29 December 1993. 
Property Rights, Recognition of Variable Capacity to Respond, Internalising Environmental Costs, In Situ Conservation, Indigenous Biodiversity Priorities, Sustainable Use, Management Actions, Precautionary Decision Making, and Focus on the Future. ${ }^{79}$ The principles provide guidance on how to achieve the goals, the values and approaches for the implementation of the Strategy, and how to resolve conflicts, although they do not prioritise one group's uses or activities over another's. ${ }^{80}$ It is implicit from the principles however, that social, economic or cultural values may not exceed the limits of sustainable use and the capacity to meet the needs of future generations. In some instances, therefore, the application of the principles will not only resolve conflicts, but may also create an informal hierarchy.

The NZBS is a significant and comprehensive approach to managing New Zealand's biodiversity. It provides a strategic framework for the conservation and sustainable use of New Zealand's biodiversity with principles to guide conflicting uses and decision-making, as well as action plans to achieve its goals. The Strategy specifically deals with the marine environment, habitat and biodiversity. The NZBS provides an invaluable insight into the principles that New Zealand could use to balance the multiple interests in the oceans as well as a strategic framework for action. Insofar as the thrust of the Strategy is not inconsistent with the Vision and the presently undetermined goals for New Zealand's Oceans Policy, it provides a positive blueprint for action.

\section{National Environmental Performance Indicators programme (EPI)}

The EPI programme is New Zealand's national system for reporting on the state of New Zealand's environmental assets. ${ }^{81}$ Monitoring the environment will assist in gaining an understanding of the environment and identifying what factors cause environmental change. It also provides a means of measuring the effects on the environment and the success of environmental policies and laws. ${ }^{82}$ The EPI programme functions as a database on which more informed policy and management decisions are based. EPIs are being developed for biodiversity, Maori and the marine environment. In relation to the marine environment EPIs include indicators for fish stock levels (for example, the level of total catch for each fish stock species by area), threatened species, the impacts of fishing, marine spills and others. ${ }^{83}$

79 Biodiversity Information Online <http://www.biodiversity.govt.nz/picture/doing/nzbs/parttwo/principles.html $>$ (last accessed 16 March 2003).

80 The New Zealand Biodiversity Strategy does, however, have a list of priority actions, which should be achieved (in no particular order) before other less fundamental initiatives are undertaken.

81 Ministry for the Environment $<$ http://www.environment.govt.nz/indicators/marine/> (last accessed 30 June 2003).

82 Ministry for the Environment, above.

83 Ministry for the Environment < http://www.marine.mfe.govt.nz/> (last accessed 16 March 2003). 


\section{Treaty of Waitangi 1840}

The Treaty provides the primary basis for Maori to realise their interests in relation to the marine environment, ${ }^{84}$ not only because Article II of the Treaty guarantees Maori tino rangatiratanga over their taonga, ${ }^{85}$ but also because of the principles of partnership, active protection and fiduciary duty, as laid down in New Zealand Maori Council v Attorney-General. ${ }^{86}$ The Treaty created a special relationship between the Crown and Mäori. The principles of the Treaty should therefore be relevant in determining the content of New Zealand's Oceans Policy. To this end, the Maori holistic view of the environment, and their traditional knowledge and practices, should be meaningfully incorporated where appropriate. Maori involvement at all levels of the development, implementation, operational and review processes will therefore ensure that the interests of the Crown's partner are actively protected. Incorporating the principles of the Treaty into the proposed Oceans Policy and attempting to work with Maori meaningfully as a joint partner should be aimed for, even though it is acknowledged that this process will not be without its problems.

\section{E Conclusion}

This Part has canvassed two of New Zealand's major international obligations as well as some aspects of its domestic legislation and policy in relation to the marine environment. A consistent theme is sustainability, either termed sustainable development or sustainable management. Further, utilisation of resources and the marine environment is provided for, although this must be balanced with protection, preservation and conservation principles. The precautionary approach, intergenerational equity, integrated management and public participation are all common themes. The principle of ecosystem integrity also seems to be present across the spectrum of obligations, except the Fisheries Act 1996, which focuses on "quota management areas". Finally, the principles of the Treaty of Waitangi are acknowledged in several of New Zealand's domestic statutes and policies.

The existing foundational legislation and obligations form the context within which any proposed marine environment management framework must mesh, or at least of which it must be cognisant. They will therefore assist in defining the broad principles to guide the proposed legislative and institutional marine management framework, set out in Part VI.

84 The other bases, aboriginal rights and developments in international law, such as the Draft Declaration on the Rights of Indigenous Peoples 1993, will not be discussed in this paper.

85 The English version of the Treaty guarantees Maori the "full exclusive and undisturbed possession of their ... fisheries and other properties ...".

86 New Zealand Maori Council v Attorney-General [1987] 1 NZLR 641 (CA). 


\section{A PROPOSED LEGAL AND INSTITUTIONAL FRAMEWORK TO MANAGE NEW ZEALAND'S OCEANS}

\section{A Introduction}

The aim of Stage Three of the Oceans Policy development process is to deliver the policies, processes and tools to achieve the Vision and Stage Two's goals and objectives. ${ }^{87}$ At present, the focus has been almost entirely on process, with no substantive content or outcomes defined other than the Vision. In this Part, therefore, I pre-empt the outcome of Stage Three by proposing a legislative and institutional framework for managing the multiple uses of New Zealand's oceans. The foregoing discussion in Part III identified three problems the current regulatory regime faces, the key problem being the lack of an overarching framework to guide stakeholders towards sustainable management of the marine environment. Part V discussed New Zealand's international obligations as well as its domestic legislation and policy initiatives. These provide the context within which I develop an Oceans Management Act (OMA), as any new law or management regime must be cognisant of existing foundational legislation and obligations. Based on the problems identified in Part III, and with the contextual reference points from Part V in mind, I propose an Oceans Management Act, Oceans Authority, New Zealand Oceans Strategy, Regional Marine Plans and Regulations, with access to the Environment Court for enforcement and dispute resolution matters. A representation of the jurisdiction of the OMA and other legislation is illustrated on page 487 and a broad pictorial overview of my proposed framework is set out on page 494 .

\section{B Purpose and Jurisdiction}

I propose that the OMA provide an overarching national framework for the management of the marine environment. This will be modelled on the Resource Management Act 1991, as that was designed to resolve a similar problem in relation to land. I would therefore envisage that the 18 major Acts that currently relate to the marine environment would be amalgamated within one comprehensive OMA. ${ }^{88}$ This will be a substantial exercise. Analogous to the RMA, the OMA will therefore provide a "one stop shop" in relation to the marine environment under the umbrella purpose of sustainable management. The intention is that all of the area under New Zealand's jurisdiction, both on land and in the sea, is sustainably managed through the RMA and the OMA. This requires a continuous flow of sustainable management practices on land, in the coastal environment and in the marine environment out to the 200 Nautical Miles (NM) mark. ${ }^{89}$ To

87 To date, these are still unidentified: see Part IV B.

88 See Part III B.

89 New Zealand's EEZ extends to the 200 NM mark, however New Zealand also has sovereign rights to the extent of its continental shelf where this exceeds $200 \mathrm{NM}$. New Zealand is required to lodge the coordinates of its continental margin with the United Nations by 2006. 
achieve this integration of purpose, the OMA will utilise the RMA and New Zealand Coastal Policy Statement's definition of sustainable management.

I envisage that jurisdiction over land and the coastal marine area would remain under the RMA. $^{90}$ The "coastal marine area" is defined under the RMA as: ${ }^{91}$

Section 2(1)

that area of the foreshore and seabed-

(a) of which the seaward boundary is the outer limits of the territorial sea:

(b) of which the landward boundary is the line of mean high water springs ...

The present problems with the management of the marine environment would be perpetuated if the management of the marine environment started from the edge of the territorial sea and extended out to the $200 \mathrm{NM}$ mark, as that would be drawing arbitrary administrative lines in the sea. I would therefore propose that the OMA's jurisdiction start from the same point as the coastal marine area, ie that the landward boundary is the line of mean high water springs mark (HWM). The seaward boundary would be consistent with the Territorial Sea, Contiguous Zone and Exclusive Economic Zone Act 1977 and extend to $200 \mathrm{NM}^{92}$ from the low water mark (LWM). ${ }^{93}$

Further, the NZCPS, which applies to the coastal environment, ${ }^{94}$ would be used as the interface between the two Acts, where the jurisdictions overlap. Although the overlap appears unnecessarily complicated, the NZCPS recognises the realities and constraints affecting the implementation of integrated coastal management, which has its own unique pressures that need to be addressed separately. ${ }^{95}$ In light of this overlap however, the composition of the decision-making body in relation to the coastal environment would likely need to be altered so that decisions incorporate the considerations of land and oceans management under the RMA and the OMA. For example, representatives from both the Regional Councils and the Regional Marine Councils (discussed AT VI C 2 "Institutional Structure") should have equal weighting in decisions relating to the coastal environment. Whilst the priorities enunciated under the NZCPS remain paramount, this interlocked

90 Resource Management Act 1991, ss 9 and 12.

91 Resource Management Act 1991, s 2.

93 Territorial Sea, Contiguous Zone and Exclusive Economic Zone Act 1977, s 9.

94 The "coastal environment" is not defined in the Resource Management Act 1991. It was judicially defined under the Town and Country Planning Act 1977 as an environment in which the coast is a significant part or element: Northland Regional Planning Authority v Whangarei County (1977) 6 NZTPA 216 (TCPAB).

95 Marcus Haward "Institutional Design and Policy Making 'Down Under': Developments in Australian and New Zealand Coastal Management" (1995) 26 Ocean and Coastal Management 87, 108. 
web of decision-making ensures that all interests in relation to the coastal marine environment, including the trickle-down effects on the land or ocean, are represented equally.

The jurisdiction of sustainable management over New Zealand's entire environment can be represented pictorially: ${ }^{96}$

Jurisdiction of the RMA, NZCPS and Proposed OMA (Figure 1)

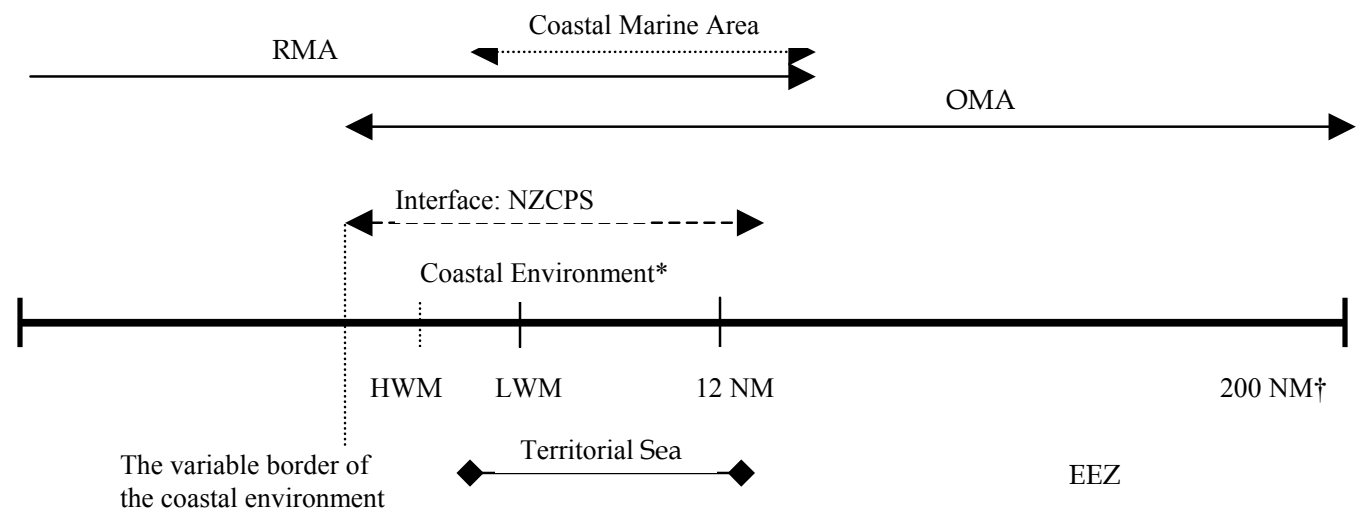

\section{Content of the Oceans Management Act}

\section{The Oceans Management Act}

Responsibility for the resulting OMA should rest, in my opinion, with the Minister for the Environment. This is because the OMA focuses on the sustainable management of the marine environment and not sectoral interests, such as solely conservation. The overarching purpose of sustainable management will need to be supported by broad principles to guide decision-makers on what matters must be considered or taken into account. The public, Maori and other stakeholders should be consulted about which values they consider to be the most significant and how these should be prioritised in relation to other values. Arguably, this has already been done during Stage One when the Ministerial Advisory Committee consulted New Zealanders about the values that should inform decision-making about New Zealand's marine environment. Whether this consultation was sufficient to assess the priorities and ranking of values will determine whether further consultation is needed. It is particularly important that stakeholders are consulted so that the

96 This is not intended to be drawn to scale. What constitutes the "coastal environment" will vary from place to place and according to the position from which a place is viewed. Where there are hills behind the coast, it will generally extend up to the dominant ridge behind the coast: Northland Regional Planning Authority $v$ Whangarei County (1977) A4828 (TCPAB).

$\dagger$ Or the extent of the continental shelf, where this exceeds $200 \mathrm{NM}$. 
legislation accurately reflects a consensus that has been agreed to at ground level, thereby ensuring greater compliance. The utilisation of broad principles is to achieve flexibility, both in relation to particular environmental circumstances in each region, as well as the flexibility necessary to ensure new and future uses of the marine environment come within the ambit of the Act.

Without trying to pre-empt the principles and views garnered from the consultation process, I suggest that, due to New Zealand's existing environmental and marine legislation and its international obligations, some principles must be incorporated into the OMA. These would include, for example, the principle of intergenerational equity, that is, that the reasonably foreseeable needs of future generations be provided for. Further, in line with the RMA and NZCPS's foci on impacts and outcomes rather than activities, any adverse effects should be avoided, remedied or mitigated in the marine environment as well. This will require Environmental Impact Assessments to be undertaken in relation to the proposed activity. Monitoring and reporting on the state of the marine environment will be necessary to recognise when a particular ecosystem or resource is not being managed sustainably. To that end, ecosystem integrity would be the basis for another broad principle, ensuring that biodiversity, ecosystems, and ecological processes are effectively maintained. Performance indicators could be utilised to measure variance over time. Furthermore, the precautionary principle should be imported into the national framework.

Integration is another key principle that must be incorporated into the OMA. Integrated management will be sought by amalgamating the 18 current Acts into the comprehensive OMA, as well as providing for an ecosystem-based approach to management founded on naturally occurring large marine ecosystems. I would propose areas no smaller than the existing regions already provided for under the RMA. $^{97}$ However, it may be more appropriate to divide the marine environment into only four marine regions, for example, the west waters off the North Island, the west waters off the South Island, the east waters off the North Island and the east waters off the South Island. Areas of this size would represent a commitment to ecological integrity by recognising naturally occurring large marine ecosystems. Integration at this level would therefore occur across current administrative boundaries. Finally, integration needs to occur across industries or sectors. Regional Marine Plans, discussed below, will aid in the prioritisation of activities although, under the OMA, all sectors will now be pursuing the same goal of sustainable management. ${ }^{98}$

97 There are currently 12 regional councils, four unitary authorities and the Chatham Islands Council, which essentially functions as a unitary authority. Unitary authorities have the combined responsibilities of a regional council and a district or city council: $<$ http://www.lgnz.co.nz/localgovt/ $>$ (last accessed $16 \mathrm{March}$ 2003).

98 Except for the special case of Crown minerals, which will pursue its own goals under the Crown Minerals Act 1991, but will also need to comply with resource consents under my proposed Oceans Management Act: see Part VI C 5 "Regional Marine Plans". 
Participatory framework for decision-making is also a vital principle. Not only should Mäori, the public and other stakeholders be involved in formulating the content of the OMA, but their contributions will be particularly important in regard to the content of Regional Marine Plans. ${ }^{99}$ The OMA should also recognise the importance of tangata whenua through a Treaty of Waitangi clause. For example, this could provide that the principles "be given effect to" or, like section 8 of the RMA, "be taken into account". Finally, the national framework should incorporate a general principle on responsibility which could include, for example, internalising costs through the polluter pays principle or user pays schemes, as well as ethical responsibilities at the business, community and individual levels.

I have raised these principles as fundamental for a national framework for the management of the marine environment. This is because New Zealand already has international and domestic obligations which form the context within which the OMA must operate and it would be imprudent to develop a framework that was not cognisant of them. However, consultation with stakeholders would not be merely window-dressing. The Oceans Authority (discussed at Part VI C 3) would consult with stakeholders in the process of developing and refining the policy. Stakeholder consultation and participation would involve debate over the extent of these principles, for example, whether the principles should be refined or broadened. Consultation with stakeholders may also reveal additional innovative or unique guiding principles. The consultation and participation process would also assist in establishing, evaluating and ranking priorities that stakeholders hold in relation to the marine environment.

The OMA would therefore provide an overarching legal framework to guide sustainable management at the national level based on the purpose and principles of the Act. The shared purpose will ensure that all policies, on land and in the marine environment, pursue the sustainable management of the environment, and consequently increase co-ordination between the different sectoral interests. Further, the OMA would provide for a New Zealand Oceans Strategy, Regional Marine Plans and Regulations. As the strategy, plans and regulations would be subordinate to the OMA they therefore need to be consistent with it. Furthermore, the broad principles under the OMA would be complemented with the necessary detail of Regional Marine Plans and regulations. The benefits of this hierarchical planning-based approach lie not only in the flexibility to respond to regional diversity within national standards, but also in sustainable management becoming the guiding purpose across the management of all activities, whether on land, the coastal environment or the marine environment.

99 Discussed in Part VI C 5 "Regional Marine Plans". 


\section{Institutional structure}

I propose that the New Zealand framework establish only one new institutional body, and rely on the current regional council structure already in place. ${ }^{100}$ One overall authority, the Oceans Authority, will be needed to regulate and co-ordinate strategic planning. ${ }^{101}$ However, New Zealand's existing regional council structure can be utilised effectively as it stands or, as I proposed above, regional councils could be combined to form four Regional Marine Councils. I believe this would be more effective as it recognises the reality of large marine ecosystems rather than council jurisdictions. If this option were adopted, the OMA would provide for four regional marine councils to be formed, naming which current regional councils and unitary authorities would be represented on each Regional Marine Council. Ideally, each existing regional council would have a designated marine officer that can sit on the respective Regional Marine Councils. If an existing region shares a coastline with two of the proposed new marine councils then they would be represented on both Regional Marine Councils. The OMA would therefore provide that particular existing regional councils work together as one unit in respect of the marine environment. They would be required to consult and collaborate on producing the Regional Marine Plan for their respective regions.

It is intended that the Regional Marine Councils be the lowest level institution as any further devolution of authority would remove the focus from the oceans back to the current jurisdictional state of affairs that the OMA is attempting to overcome.

\section{The Oceans Authority (the Authority)}

A centralised Oceans Authority, responsible to the Minister for the Environment, will need to be established to co-ordinate oceans issues across central government and Regional Marine Councils, as well as work in partnership with the tangata whenua of the area. I propose that the Authority be comprised of representatives from central and local government, a Maori representative, suitably qualified marine or coastal experts, and a member with international law experience. This group will have a breadth of knowledge and experience that can be applied practically to the management of the marine environment.

I visualise the Authority as having both strategic and regulatory functions. It will therefore be involved in formulating the New Zealand Oceans Strategy, providing advice and making recommendations to the Minister for the Environment on the strategic directions of the policy. In particular, after extensive stakeholder consultation, the Authority will be the primary body charged with policy development and refinement. Subject to Ministerial approval, it will be responsible for the difficult task of resolving policy inconsistencies, for example, aligning quota management areas

100 Although, as discussed in Part IV B, the composition of the decision-making body in relation to the coastal environment may have to be altered in light of the overlap in jurisdiction.

101 Discussed in VI C 3. 
under the Fisheries Act 1996 with the broad principle of ecosystem integrity. The Authority will also approve Regional Marine Plans and review the OMA after three years to evaluate whether the goal of sustainable management is being met. Further, it will have regulatory functions such as ensuring compliance, and monitoring and reporting to government on the state of the marine environment. In order to fulfil its ongoing monitoring role, the Authority will need to be adequately resourced.

The Authority will also be involved at two levels of dispute resolution. First, it will formulate the national policies for the New Zealand Oceans Strategy and list a set of priorities, which should resolve conflicts as they arise. Secondly, the Authority will provide a mediation service. The mediation service will travel the country and mediate disputes in the first instance. If the mediation service is unable to resolve the issue, parties may appeal to the Environment Court. ${ }^{102}$

4 The New Zealand Oceans Strategy (the Strategy)

As mentioned above, the formulation of the Strategy will primarily be the Authority's responsibility, although the preparation and subsequent amendments of the Strategy would need to be publicly notified and developed in consultation with the public, tangata whenua and other stakeholders. The Strategy will therefore be the highest level of policy in regard to the marine environment and will set a framework and national standards within which Regional Marine Plans must be consistent.

\section{Regional Marine Plans}

Marine plans would be developed on a regional or even multi-regional basis (see above). This would allow naturally occurring large marine ecosystems to be recognised, rather than having a process based on administrative boundaries that may cut across marine processes. The Regional Marine Plans would be subordinate to the OMA and the Strategy, providing greater detail and, concomitantly, greater certainty for users in each region or combined region. Like regional plans under the RMA, Regional Marine Plans would be required to be consistent with the OMA's purpose and principles and with the policies under the Strategy, thereby ensuring that national standards are adhered to.

An important aspect of the regional planning process under the RMA, which would be incorporated into the process for the design of Regional Marine Plans, is participation and consultation. Provision should therefore be made for the participation of the tangata whenua of the area and other stakeholders in the formulation of the Regional Marine Plans. As well as being responsive to the needs of the community and its environment, this "buy in" contributes to credible, accepted rules and responsibilities for stakeholders.

102 Discussed at VI C 7. 
The contents of Regional Marine Plans would cover much of the contents of regional plans under the RMA as is relevant to the marine environment. For example, Regional Marine Councils would state, amongst other things, the issues to be addressed in the plan, the objectives to be achieved, the policies behind those issues and objectives, and the environmental results anticipated from the implementation of these policies and methods. ${ }^{103}$ Furthermore, Regional Marine Councils would be able to grant resource consents where an activity would otherwise contravene the OMA and the actual and potential effects of allowing the activity had been assessed. ${ }^{104}$ In the special case of Crown minerals and petroleum, applicants would therefore have to go through both the process for obtaining a resource consent under the OMA and the process for obtaining a permit under the Crown Minerals Act 1991. This is currently the process under the RMA and I propose that the dual regime be carried over to the marine environment.

Regional Marine Plans would also be used as the basis from which implementational and operational details will be discernible. The plans would therefore need to be quite detailed. After consultation, the Regional Marine Plans would reflect the particular circumstances and priorities of the region and the community. Thus, differing objectives could be sought across the different regions allowing some discretion to meet the particular needs or new circumstances. These, of course, would be subject to the national purpose and principles of the OMA, providing scope for regional solutions without compromising national consistency.

\section{Regulations}

Provision would also be made for the drafting of regulations under the OMA. As with the Strategy and plans, these must not be inconsistent with the OMA. The regulations would deal with regulatory matters such as taking immediate and temporary measures in the event that performance indicators indicate an emergency in the marine environment or its resources, providing for charges and fees to be imposed on certain activities (such as ocean dumping), setting out offences and their penalties, and the designation and powers of enforcement officers.

Regulations would therefore allow a quick response to changed or emergency circumstances in the marine environment. They are also a suitable repository for the policy's finer details.

\section{The Environment Court}

The Environment Court, or a dedicated marine branch of it, would provide the necessary support for my proposed oceans management framework. The Environment Court is suitable because the structure is already present for sustainable management in relation to land and the coastal environment. It therefore appears logical to extend the court's jurisdiction to the marine

103 These examples are taken from the Resource Management Act 1991, s 67.

104 This uses the same test that decision-makers use in relation to an application for a resource consent under Resource Management Act 1991, s 104. 
environment, so that claims concerning land and the marine environment do not need to be lodged in two different courts. Furthermore, environmental expertise within the Environment Court can be drawn on in relation to marine issues.

The Environment Court's functions would be to act as the second layer of dispute resolution, that is, to adjudicate where mediation had not been successful, to enforce compliance with the various aspects of the legal framework and to deter similar conduct through imposing effective sanctions for breach. The existing Environment Court, if adequately resourced, is well placed to fulfil these functions.

\section{Conclusion: The Legal Effect of the Oceans Management Framework}

The legal and institutional framework described above can be displayed diagrammatically (see Figure 2 on next page).

Regional Marine Plans and regulations, which are subordinate to an Act based on an overarching purpose of sustainable management and broad guiding principles, would therefore be responsive to regional diversity and regional priorities within national standards. Importantly, the focus will be on the effects of activities and their impacts on the environment, rather than solely managing the activity. Furthermore, greater detail can be provided for in subordinated legislation, as well as a greater capacity to respond to emergencies and other changed circumstances due to the quicker timeframe to amend regulations rather than changing the law through Parliament. By providing a hierarchy of policies and regulations, I believe the OMA will provide a strategic planning and management framework for dealing with the current ad hoc nature and lack of coordination in the marine environment. Community and stakeholder decision-making is also provided for.

The OMA should also assist marine users to resolve conflicting interests in advance by using the broad principles under the OMA and the Strategy, and the specific objects under Regional Marine Plan. This should therefore provide users with some degree of certainty as well as the ability to anticipate the probable framework within which they must act where there is no precedent. However, where a certain outcome is not apparent or a clear hierarchy of priorities cannot be ascertained from the Regional Marine Plans, parties may resort to the mediation service under the Oceans Authority or, failing resolution at that level, the Environment Court. 
Figure 2

Oceans Management Act

- Minster for the Environment

Purpose:

- Sustainable management: definition from RMA

Principles:

- Intergenerational equity

- Avoid, remedy, mitigate adverse effects

- Ecosystem integrity

- Precaution

- Integration

- Participatory framework for decision

making

- Treaty of Waitangi

- Responsibility

- Others, discerned from consultation

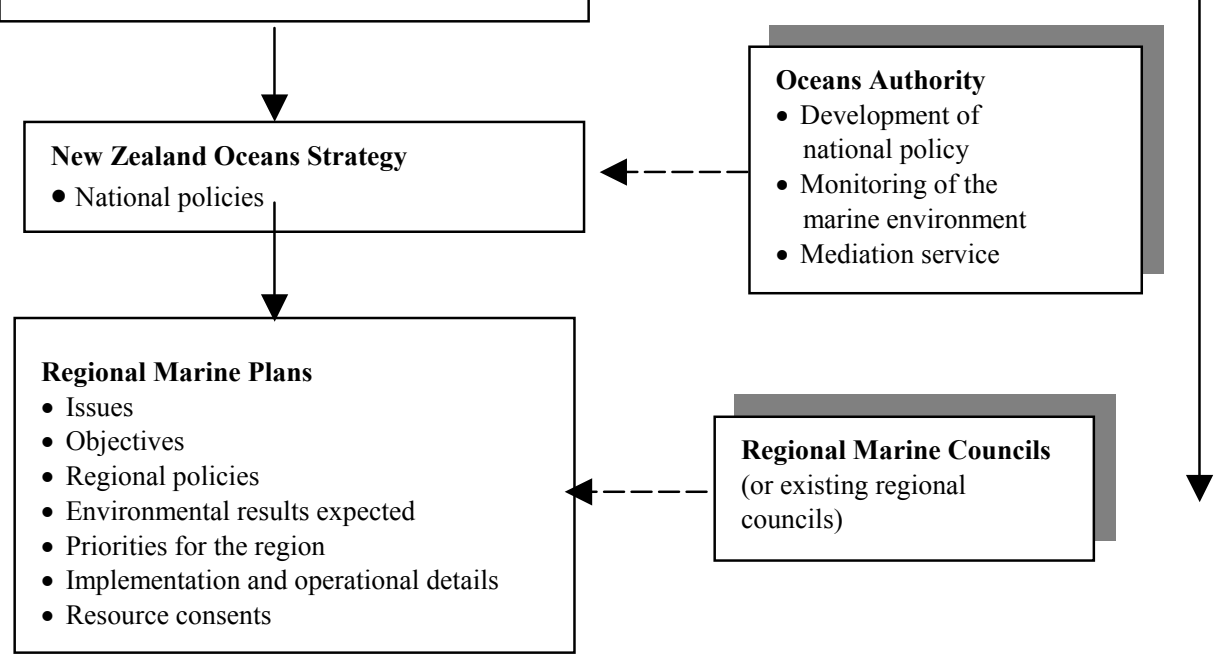

Regulations

- Detailed regulatory matters 
Finally, for my proposed oceans management framework to be a reality and to be effective, dedicated funds must be appropriated. Funds are not only necessary for the institutional and implementational aspects discussed above, but also to provide for substantial and much needed research, so that decisions can be based on the best available scientific information. Although internalising environmental costs through polluter or user pays principles will recover some of the costs, additional funding will be required to ensure that communal rights, such as access to the oceans and other public amenity values, do not become subsumed under a user-pays system.

\section{CONCLUSION}

This paper has proposed a legal and institutional framework for the management of New Zealand's marine environment and its resources. The aim of the Oceans Policy is to develop an integrated and comprehensive framework in relation to the sustainable management of the marine environment. The framework will need to ensure that current users of the marine environment will know with certainty the extent of their rights and responsibilities, and that users can predict with some certainty the regime that will apply in respect of future ocean and resource uses. Although the comprehensive nature of such a proposal is an essential element, it is also vital that any scheme remain flexible in order to respond to changing patterns of use and changes within the environment itself. It must also be broad enough to cope with the range of user groups and interests, including where new uses and issues come into being. The marine management framework must provide clear guidance and firm boundaries, with effective penalties for non-compliance.

There are many indicators to inform the content of New Zealand's Oceans Policy. New Zealand's existing foundational legislation and obligations demonstrated a commitment to certain principles that any proposed oceans management scheme should not be ignorant of. For example, sustainable management, intergenerational equity, ecosystem integrity, precaution, integration, participatory decision-making, principles of the Treaty of Waitangi and responsibility.

I have proposed a framework that is cognisant of and accommodates New Zealand's existing obligations. The framework would recognise the physical realities of the ocean by adopting an ecosystem-based approach to management as well as integrate the current fragmentation of decision-making. I would achieve these two goals by amalgamating all the current legislation into one comprehensive Act, the new Oceans Management Act. This would abolish the current administrative and sectoral approaches to the management of the marine environment that is currently characterised by a disarray of often conflicting Acts and agencies. Instead, the OMA would be based on the natural boundaries of large marine ecosystems.

I believe that my proposed comprehensive framework would therefore provide the necessary balance between the flexibility to accommodate various interest groups, be able to respond to regional diversity whilst providing the security and certainty required by present and future users of the marine environment. 
The above explication of my proposed OMA is an example of one option, in a sea of many, for the sustainable and integrated management of New Zealand's marine environment. However, a task of such magnitude will necessarily involve a substantial investment of time, labour and resources as New Zealand moves from the current administrative and sectoral based management system to an integrated management regime. To be successful, adequate resources will therefore need to be committed to the new institution or institutions and the policy's associated implementational and operational costs. After careful consideration of the issues, it is my view that both the effort required and the dedication of adequate physical and financial resources to New Zealand's Oceans Policy are warranted. Indeed, the costs of getting it wrong are simply too great, and too irreparable, to consider.

New Zealand has the opportunity to lead the development of an Oceans Policy that sees its oceans as one component of a global entity. In a system that sees the ocean as one whole with thousands of interacting parts, New Zealand's and other countries' individual efforts may not be enough to sustain the life-supporting capacity of the oceans. This is a global problem. It does not end at the $200 \mathrm{NM}$ limit of coastal states. Countries that take a national, rather than a supranational approach to such issues may be missing the wood for the trees.

New Zealand should aspire to be a world leader in showing responsibility to an asset that holds one of the few keys to the future of the planet and its peoples. 